\title{
Classroom Management at Primary Schools in Mataram: Challenges and Strategies
}

\author{
Lalu Hamdian Affandi* \\ Primary School Education Study Program \\ Universitas Mataram \\ Mataram, Indonesia \\ hamdian.fkip@unram.ac.id
}

\author{
Heri Hadi Saputra \\ Primary School Education Study Program \\ Universitas Mataram \\ Mataram, Indonesia
}

\author{
Husniati Husniati \\ Primary School Education Study Program \\ Universitas Mataram \\ Mataram, Indonesia
}

\begin{abstract}
This qualitative research aims to describe the challenges and strategies applied by primary school teachers in Mataram in conducting classroom management. This study was designed with a narrative approach to express the teacher's experience in conducting the classroom management. Data were collected through interviews, observation, and documentation namely lesson plan and teacher's notes dealing with the implementation of classroom teaching and learning. The research found that the main challenges of teachers in managing classrooms are the teachers' understanding of classroom management and their assumptions about good students. For teachers, good students are students who obey the teacher's orders and have high motivation in learning, while the class is considered as physical environment that is entirely under the teacher's responsibility to be arranged. Regarding classroom management strategies, teachers tend to be reactive with a primary focus on the physical aspects and less attention on the social-emotional aspects of the class. When dealing with students' behavior problems, the teacher prefers a behavioristic approach. Thus, this study recommends that teachers should be given a wider access to the development of classroom management theory and practice so that they are able to develop integrative class management by involving students as the learning subjects. The future researches need to be directed to measure the effects of classroom management strategies on other variables such as learning motivation, attitudes toward teachers and learning material, student learning involvement, and the learning outcomes.
\end{abstract}

Keywords - class management, primary school teachers

\section{INTRODUCTION}

Classroom management is the process of forming a learning environment that is conducive for students. A good learning plan cannot run smoothly when the classroom atmosphere is noisy, there is a lot distraction for students' attention, and the classroom atmosphere is physically and socially uncomfortable. The main purpose of classroom management is to create an environment that is conducive to the learning process. More specifically, classroom management aims to reduce the students' disruptive behavior, create effective and productive social interactions in the classroom, and organize a comfortable and healthy classroom physical environment for learning.

Classroom management activities are generally classified into 3 major groups of activities that are controlling student behavior, creating effective and productive social interactions, and structuring the physical classroom environment [1]. Simonsen, et al., [2] recommend 20 good practices that are supported by the research results in classroom management. The 20 good practices are classified into five main characteristics, namely maximization of class structure, expression and realization of teacher expectations, actively involving students in the observed behavior, the use of strategies that accommodate appropriate student behavior, and the use of strategies to respond to unwanted behavior. In its implementation, classroom management strategies can be manipulated and combined according to the context in which the teacher teaches.

The fact of classroom management as found by the previous studies shows that the classroom environment is not conducive enough as a place of learning. This can be seen from the monotonous room setting where students sit or line up and it is not adapted to the teaching and learning needs. At the same time, students' interaction patterns are very limited as students only spend most of their learning hours by listening and taking notes on the teacher's explanation. As a result, disturbances in the form of noise, boredom, constrained feelings in expressing themselves make students' attention split and ultimately disrupt the learning activities.

Many studies have proven the urgency of classroom management in supporting the convenience of students in learning. The meta-analysis conducted by the experts found that the effect size of classroom management on learning involvement was +0.617 and +on student achievement was 0.512 [3]. Good classroom management has been found to reduce student disruptive behavior, increase motivation, interest, and student learning satisfaction [4]. Furthermore, Marzano and Pickering [3] concluded that classes managed with effective disciplinary procedures have fewer deviant behaviors than classes that are managed without good disciplinary mechanisms. The lack of deviant behavior in the classroom fosters a comfortable social-emotional atmosphere. The comfort classroom atmosphere is an important factor in student learning achievement [5].

Although research on classroom management and its effects on the process and learning outcomes have been done many times, there are still problems dealing with bad classroom management systems. This means that research findings dealing with classroom management need to be continuously transferred into learning practices [2]. The transfer of research findings classroom management requires adaptation according to the context in which problems occur. The relationship between context and class management is often overlooked by the previous studies [4]. Class is a complex environment hence the efforts to understand its dynamics are not enough just to rely on one method or source of information [6]. For this reason, there is a need for 
a research that is able to produce a detailed, contextual, and comprehensive picture of the real problems faced by teachers in classroom management. This narrative research aims to provide a comprehensive and detailed picture of the challenges and strategies of teachers in conducting classroom management at primary schools in Mataram.

\section{METHOD}

This is a qualitative research with a phenomenological narrative design, in which researchers examined the perspectives diversity of teachers and students in interpreting the classroom environment and in how to manage it. This study is said to be phenomenological because the researchers mostly use native perspectives in understanding the phenomena and behavior of research subjects [7]. In this case, researchers recorded and described the way teachers and students interpreted the meaning for the phenomena of teacher-student interaction, disciplining student behavior and structuring classrooms.

The data in this study were obtained from the informants who were selected based on their activeness in the research field, their availability of time, and the originality of their information [8]. Based on these criteria, the researcher chose the teacher and students as the main informants and also the principal and parents as additional informants. This research was conducted at SDN 30 Mataram which is located in the center of Mataram City. Most of the teachers in this school are civil servant who have bachelor degree and educator certificate

Data in this study were collected through interviews, observations, and documentation. Interviews were conducted to collect data about considerations, values, beliefs, teachers' knowledge about classroom management, and challenges faced by teachers in conducting the classroom management. The interview format used was in-depth interviews with the interview general compiled guidelines. Observation was used to record the class atmosphere when the teacher is managing the class, such as teacher's behavior in the classroom, students' behavior, and the atmosphere during the teaching and learning process. In making observations, researchers recorded the detailed events during the learning process. Moreover, observations were conducted to observe the patterns of communication between a teacher and the other teacher in discussing the classroom management problems. The type of observation used in this study was direct observation by chronological recording and detail of the target of observation. Documentation is a technique of collecting data through written notes owned by research informants. Documentation was conducted to dig up data about the lesson plans made by the teacher, teacher's notes related to the events and students' behavior in the classroom, and also the teacher and student attendance at school. The target documentation in this study is a document in the form of a teacher's lesson plan, a teacher's diary, also teacher and student attendance list.

Data analysis in this study began from data collection to the data were considered sufficient to answer the research questions. The data analysis aims to find out themes from the scattered information obtained through interviews, observations, and documentation. To find the theme of the information obtained, the researchers conducted data reduction, data display, and data verification and conclusion.

\section{RESULTS AND DISCUSSION}

In general, classroom management challenges faced by teachers can be classified into challenges that come from the teacher and students. The internal challenges related to the teacher ability is a challenge that manifested in the form of assumptions, knowledge, and teacher skills. Meanwhile, external challenges arise from the conditions in which the teacher is on duty, namely the classroom and the students.

Within the internal challenges, teacher has a limited understanding on classroom management in which the teacher interprets classroom management as a series of activities that focus on physical aspects of the class such as the arrangement of seating and class facilities. It is known from the teachers' statement who considers that "the class management is an activity of organizing all the objects in the class such as student's seats, teacher's desks and chairs, whiteboards, and bookcases". The limited understanding toward the focus of classroom management can also be seen from the description for the ideal class. In this case, the teacher describes the ideal class as a place where students freely look at the teacher and the blackboard, thus, placing items in the classroom neatly will not prevent students from seeing the teachers in explaining the lesson.

Besides the knowledge of classroom management, another challenge identified was the teacher's understanding the rule applied in the classroom. In this case, teachers tend to equate the rule for school with that for classroom. For teachers, school rules are guide for the behavior of students. The teacher considers the classroom rule as the order of behavior that students must obey. This kind of rule has already been there since the teacher first entered the class. The rule is posted on the classroom wall and it contains the codes of conduct such as the way of dressing and the procedure for maintaining the class cleanliness.

The way teachers ensure that student behavior is in accordance with the rules cannot be separated from their assumptions about good students. For teachers, good students are students who are academically motivated and socially skilled. "Good students are diligent students who want to do and finish the assignment on time. When they are given the opportunity to ask questions, they use it to ask questions that they do not understand". On another occasion, the teacher stated that good students were "students who are obedient, respect the teachers, and do not like to disturb their friends".

In addition to internal challenges, external challenges in classroom management for teachers are related to student behavior. For teachers, student behavior is one of the biggest challenges in conducting the classroom management. Even though most students behaved well based on the rules, there are still a number of students who disobey the rules especially those behaviors dealing with respectability. One of the teachers states that "it sometimes difficult to educate nowadays children to be respectful. There were some students who repeatedly bothered their friends, and some of them lacked the enthusiasm for learning, this may be caused by the their internal family factors, such as lack of attention from their parents, divorce between their father and mother, and their parents become migrant workers". 
To overcome these challenges, teachers should organize the physical environment of the classroom so that students feel comfortable in learning and they can discipline students by socializing rules of the school and imposing sanctions on students who break the rules. Organizing classroom's physical environment is to create the comfort learning environment - a classroom atmosphere that makes students feels like at home. Therefore, the class should be managed with the principles of neatness, cleanliness, and beauty of the classroom environment. Teacher says that in managing the classroom, things that need to be considered are the class neatness and cleanliness. Neatness needs to be created in order to make a comfortable class in the teaching and learning process. Beauty can be created by putting flowers in the classroom. Based on these ideas, we can conclude that the way the teacher manages the classroom physical environment is by placing objects and items based on its function to create convenience for teacher and students during the learning process.

In terms of student behavior, teacher can discipline the students gradually by socializing the classroom orders and imposing sanctions on students who break the orders. On an interview, teacher tells that to ensure the students understand the classroom rules, he explains the contents of the class orders in detail. Socialization of classroom rules is usually carried out at the beginning of the semester by using pamphlets attached on the classroom wall. As the whole students are assumed to have understood the classroom rules, teacher can discipline the students by imposing sanctions for each violation. A teacher who teaches in grade four states: "... I initially watched students in order to make sure they behaved in accordance with the orders. When I encountered students who break the orders, I gave them a warning so they do not do the same mistakes again. If they still do the mistake - breaking the rules, I gave them sanctions like standing in front of the class, getting additional homework, or even being expelled from the classroom".

The description of the challenges and strategies for classroom management above indicates that classroom management did by teachers was not comprehensive. Ideally, classroom management is not only dealing with organizing the physical environment of the classroom, but also creating a productive socio-emotional atmosphere through disciplinary mechanisms that are integrated with the learning activities. Organizing the physical environment is only intended to facilitate students to access learning resources, mobility in completing assignments, and good interaction in collaborative work in the classroom.

Moreover, classroom management activities also include controlling student behavior and creating effective and productive social interactions [1]. Controlling student behavior refers to a series of teacher activities in ensuring students' behavior that is oriented towards completing tasks in achieving predetermined learning outcomes. Effective and productive social interactions are reflected by the freedom of expression and giving opinions, acceptance of diversity, and the development of harmonious cooperative patterns in achieving the learning goals. Focusing on the physical environment of the class only will certainly distort the meaning of real class management. Even though dirty classroom environment will trigger unexpected actions and create a non-conducive classroom atmosphere, other aspects of classroom management must be considered by the teacher.

In relation to disciplining student behavior, teachers use a more behavioristic approach which some experts criticized as it considers students as passive and non-initiative individuals. In general, the behavioristic approach emphasizes more on the teacher's efforts to eliminate disruptive behavior and encourage the expected behavior. Expected behavior is behavior that students must have in accordance with the classroom orders. Conversely, disruptive behavior is behavior against class norms and order that students should not have. Eliminating disruptive behavior and fostering expected behavior can be carried out with a mechanism of reward and punishment, where disturbing behavior will be given punishment, while the expected behavior will be given a reward [4]. Behavioristic approach that is not based on the core issues dealing with deviant behavior will certainly trigger the emergence of new problems related to student behavior. In this case, the teacher must understand the mechanism of disciplining behavior that should be from preparing the classroom order. Classroom order consists of two major parts; the rules and procedures. Rules are principles of general behavior, while procedures are rules of specific behavior [3]. If teacher considers that the classroom rules are only limited on principles, then the rules of more specific behavior in accordance with the context of the teaching methods and media are ignored. As a consequence, the students will only become listeners and wait for the teacher's commands without the initiative to be creative in learning.

\section{CONCLUSION}

The challenges faced by teachers in managing classrooms in primary schools come from the capacity of teachers and students in the classroom. In relation to teachers' capacity, the challenges deal with the teacher's understanding of classroom management and assumptions about good students. Teachers' understanding becoming a challenge because teachers only understand class management based on the physical aspects of the class. This is inseparable from their assumption that good students are students who have motivation to learn and are socially obedient, respect teachers, and do not like to behave disruptively. To overcome these challenges, teachers implement strategies that tend to be reactive in which they used series of actions in managing the classroom, especially in disciplining students when the undesirable behaviors happen.

Thus, in order to expand the teachers' understanding, teachers need to be given wider access to classroom management theory and studies through more comprehensive and interactive research, socialization, workshops and research activities. In addition, this study suggests that further researches should identify the factors that cause the challenges of classroom management for teachers, and they also should be directed to help teachers create classroom management strategies that are integrated with a series of learning management, such as the preparation of learning plans, the selection of teaching method and media as a preventive measure to avoid the unexpected behavior and comprehensive evaluation mechanisms in order to make 
classroom management as an inseparable part of the teaching and learning system.

\section{REFERENCES}

[1] McLeod, J., Fisher, J., and Hoover, G. The Key Elements of Classroom Management; Managing Time and Space, Student Behaviour, and Instructional Strategies. Alexandria, VA; ASCD, 2003.

[2] Simonsen, B., Fairbanks, S., Briesch, A., and Myers, D. Evidence-based Practices in Classroom Management; Considerations for Research to Practice. Education and Treatment of Children, 31 (3), 2008, 351-380.

[3] Marzano, R.J., Marzano, J.S., Pickering, D.J. Classroom Management That Works; Research-based Strategies for Every Teacher. Alexandria, VA; ASCD, 2003.

[4] Seiz, J., and Kunter, M. Classroom Management; Current Research in the Light of Social Psychology. In Christine M.Rubie-Davies, Jason M. Stephens, and Penelope Watson (Eds.). The Routledge International Handbook of Social Psychology of The Classroom. New York; Routledge, 2015, p. 242-251

[5] Reyes, M.R., Brackett, M.A., Rivers, S.E., White, M., and Salovey, P. Classroom Emotional Climate, Student Engagement, and Academic Achievement. Journal of Educational Psychology. Advance Online Publication, 2012.

[6] Ruzek, E.A., and Pianta, R.C. The Value of Using Obervational and Student Report Methodologies in Classroom Research. In Christine M.Rubie-Davies, Jason M. Stephens, and Penelope Watson (Eds.). The Routledge International Handbook of Social Psychology of The Classroom. New York; Routledge, 2015, p. 231-241.

[7] Creswell, J.W. Educational Research; Planning, Conducting, and Evaluating Quantitative and Qualitative Research, Fourth Edition. Boston, MA; Pearson Education Inc., 2012

[8] Fraenkel, J.R., and Wallen, N.E. How to Design and Evaluate Research in Education, Seventh Edition. New York; The Mcgraw-Hill Companies, Inc., 2009. 